\section{Growth, Nitrogen Use Efficiency, and Leachate Comparison of Subirrigated and Overhead Irrigated Pale Purple Coneflower Seedlings}

\author{
Jeremy R. Pinto ${ }^{1}$, Rhiannon A. Chandler, and R. Kasten Dumroese \\ Southern Research Station, USDA Forest Service, 1221 South Main Street, \\ Moscow, ID 83843
}

Additional index words. Echinacea pallida, mortality, runoff, electrical conductivity

\begin{abstract}
Pale purple coneflower [Echinacea pallida (Nutt.) Nutt.] was grown within three container volumes $\left(90,105\right.$, and $\left.340 \mathrm{~cm}^{3}\right)$ under subirrigation and overhead irrigation treatments. Subirrigated coneflowers showed increased seedling quality with more biomass $(14 \%)$, better nitrogen use efficiency $(13 \%)$, greater nitrogen content $(\mathbf{N}$; $11 \%)$, more height $(15 \%)$, and lower mortality compared with overhead-irrigated seedlings. Plants also showed increasing height, biomass, and $\mathbf{N}$ content with increasing container volume. Overhead irrigated coneflowers had more leachate compared with subirrigated seedlings, which produced none. Leachate electrical conductivity and $\mathbf{N}$ were monitored throughout the growing season and decreased at similar rates, whereas subirrigation effluent levels remained constant. Subirrigation offers a viable alternative to traditional overhead irrigation systems by producing this native plant with equal or better quality without discharging potentially harmful leachate into the environment.
\end{abstract}

Native plants for ecosystem restoration are commonly grown in containers in greenhouses. Within greenhouses, overhead irrigation is the most widely used system to irrigate plants (Leskovar, 1998). Overhead irrigation systems are chosen for their simplicity, low cost, and for reducing fertilizer salt buildup, which can be detrimental to plant growth (Argo and Biernbaum, 1995; Biernbaum, 1992; Molitor, 1990).

Unfortunately, overhead irrigation also has potential negative attributes, namely wasted water and the nutrients with it that may harm the environment. Dumroese et al. (1995) found that between $49 \%$ and $72 \%$ of water applied to a native plant seedling crop using an overhead boom irrigation system was discharged from the nursery. Moreover,

\footnotetext{
Received for publication 24 Jan. 2008. Accepted for publication 12 Feb. 2008.

Funding for this work was provided by USDA Forest Service, State and Private Forestry, Cooperative Forestry through the Reforestation, Nurseries, and Genetic Resources Virtual Center.

A portion of this manuscript was submitted by R.A.C. in partial fulfillment of a senior thesis project at the Univ. of Idaho.

Mention of a trademark, proprietary product, or brand names does not constitute a guarantee or warranty of the product by the USDA Forest Service and does not imply its endorsement or approval to the exclusion of other products that also may be suitable.

We thank Ann Abbott for statistical consulting, Seth Novak for processing nitrogen water samples, and Amy Ross-Davis for manuscript editing.

${ }^{1}$ To whom reprint requests should be addressed; e-mail jpinto@fs.fed.us.
}

such inefficient irrigation systems may pose an unnecessary high cost to growers where quality water is limited. Some states, including California and Arizona, impose restrictions on water use during dry seasons, which can further increase the need for water conservation in nurseries (Oka, 1993).

Waste water discharged from nurseries presents a significant threat to ground and surface water; the primary concern involves the release of nutrients resulting from regular use of water-soluble fertilizers. Because the rate of fertilizer application is higher in forms of agriculture (Molitor, 1990), nitrate and phosphate runoff from greenhouses may contaminate water resources (Biernbaum, 1992; Juntenen et al., 2002). In a leaching study during conifer seedling production, $11 \%$ to $19 \%$ of applied nitrogen $(\mathrm{N})$ and $16 \%$ to $64 \%$ of applied phosphorus (P) were recovered in collected leachate (Juntenen et al., 2002). Similarly, $46 \%$ to $65 \%$ of applied $\mathrm{N}$ was recovered in collected leachate (as $\mathrm{NO}_{3}-\mathrm{N}$ ) for overhead irrigation experiments on Ilex crenata Thumb. 'Compacta' (Fare et al., 1994). The continuous effect of high nutrient leaching may become a problem over time. Very high $\mathrm{N}$ levels may accumulate and persist under commercial greenhouses (McAvoy et al., 1992; Molitor, 1990) threatening groundwater quality. Consequently, discharges may be legally regulated in the future; such restrictions already exist in Oregon (Grey, 1991).

Subirrigation, instead of overhead irrigation, has potential to reduce water use and chemical runoff from nurseries while improving crop uniformity and reducing labor (Uva et al., 1998). This closed system works greenhouse production than many other by permitting water to move from a reservoir tank to an application tray, where water then moves through the growing medium by capillary action (Coggeshall and Van Sambeek, 2001). Once irrigation is complete, any unused water drains into the holding reservoir for later recirculation through the system. Dumroese et al. (2006) demonstrated a $56 \%$ water savings over conventional overhead irrigation for Metrosideros polymorpha Gaud., whereas Ahmed et al. (2000) showed a water savings of $86 \%$ for food crops.

Subirrigation may improve crop uniformity because plants have access to equal amounts of water thereby reducing or eliminating the edge effect (Neal, 1989). Part of this improvement is because subirrigation avoids problems with canopy interception and redistribution from overhead irrigation systems. In container nurseries, as leaf area and density increase, irrigation application efficiency decreases (Beeson and Knox, 1991). Consequently, container size may also affect irrigation efficiency, e.g., small container sizes at high densities combined with large leaf areas will likely cause a decrease in efficiency. Along the same lines, studies characterizing water use have found improved efficiency in subirrigation versus overhead irrigation systems (Morvant et al., 2001; Santamaria et al., 2003), assuming tanks are not emptied and refilled regularly. Similarly, because no nutrients are lost from the system, nutrient use efficiency has also been shown to be similar or better in subirrigation systems, especially when combined with controlled-release fertilizer (Morvant et al., 2001; Richards and Reed, 2004). Further benefits may include improved growth and flowering, as Yeh et al. (2004) saw with forbs.

Despite the numerous advantages of subirrigation, potential concern exists. One concern is the accumulation of salts within the upper portion of the growing medium profile, especially under increasing fertilizer concentration regimes (Kent and Reed, 1996; Richards and Reed, 2004; Todd and Reed, 1998). Depending on species, these levels may or may not pose problems, including salt burn, reduced growth, and interference with mineral nutrient uptake (Dumroese et al., 2007); Scoggins (2005) summarizes acceptable electrical conductivity (EC) ranges for several herbaceous perennials. In situations where high salinity levels become problematic, leaching through overhead irrigation may help (Todd and Reed, 1998).

Although a number of studies have highlighted the effects of subirrigation and controlled-release fertilizer, few have specifically addressed the potential for native plant production. This study was undertaken to gain a better understanding of subirrigation as a viable and environmentally conscious alternative for native plant propagation. Our study objectives were to quantify the effects of irrigation and container size on plant height, biomass, and survival; nutrient use and efficiency; and fertilizer leaching. 


\section{Materials and Methods}

Nursery culture. We chose the native plant pale purple coneflower [Echinacea pallida (Nutt.) Nutt.] for its broad geographic distribution and its large canopy as a seedling. The seedlings were greenhousegrown in Moscow, ID $\left(41^{\circ} 43^{\prime \prime} 33^{\prime} \mathrm{N}\right.$, $117^{\circ} 00^{\prime \prime} 37^{\prime} \mathrm{W}$ ) using three types of Styrofoam ${ }^{\circledR}$ containers (Beaver Plastics Ltd $^{\circledR}$, Edmonton, Alberta, Canada; and BC First Choice $^{\circledR}$, Mansonville Plastics Ltd., Surrey, B.C., Canada) under subirrigation and overhead irrigation treatments. The Styrofoam ${ }^{\circledR}$ containers, sometimes referred to as blocks or trays, are comprised of numerous cavities of specified dimension; container nomenclature and characteristics are provided in Table 1. The subirrigation system consisted of three separate, benchtop, plastic trays $(1.2 \mathrm{~m} \times$ $2.4 \mathrm{~m} \times 0.05 \mathrm{~m})$ each outfitted with a $375-\mathrm{L}$ tank, pump, and drain tube (Ebb-Flo; Midwest GroMaster Inc., St. Charles, IL). The overhead irrigation system was a traveling boom (set at $\left.0.05 \mathrm{~m} \cdot \mathrm{s}^{-1}\right)$; nozzles $\left(110^{\circ}\right.$ flat spray tip) were spaced at $0.26 \mathrm{~m}$ and were $0.77 \mathrm{~m}$ above the container. Seeds were sown in late May 2005 and grown for $93 \mathrm{~d}$.

Six containers of each size were filled with a 1 Sphagnum peatmoss : 1 vermiculite (by volume) medium (Phillips Soil Products, Molalla, OR) amended with Apex ${ }^{\circledR} 14 \mathrm{~N}-6 \mathrm{P}-$ 11.6K controlled-release fertilizer (3- to 4-mo release rate; JR Simplot Company, Boise, ID) at $3.17 \mathrm{~kg} \cdot \mathrm{m}^{-3}$. Seeds were sown and media brought to field capacity and weighed. One container of each size class was randomly assigned to each of three overhead irrigation tables and three benchtop subirrigation trays. The three tables and three trays were randomly located throughout the greenhouse. As required, containers were misted with the overhead irrigation system to promote germination. After germination, seedlings were thinned to one plant per cavity; every cavity in every container had one plant. Subsequent irrigation timing was based on target gravimetric container weights of $85 \%$ (White and Marstalerz, 1966).

For the overhead irrigation treatments, each container was monitored and irrigated separately as needed to bring the container back to field capacity. For the subirrigation treatment, as a result of logistical constraints, all containers were irrigated when one dropped below $85 \%$. Water was cycled into the subirrigation trays as often as needed for the containers to return to field capacity; tanks were refilled as necessary. Containers were randomly rotated within subirrigation trays

Table 1. Styrofoam ${ }^{\circledR}$ container specifications for the production of coneflower seedlings.

\begin{tabular}{lcccc}
\hline & \multicolumn{4}{c}{ Cavities } \\
\cline { 2 - 5 } Container $^{z}$ & $\begin{array}{c}\text { Number per } \\
\text { container }\end{array}$ & $\begin{array}{c}\text { Volume } \\
\left(\mathrm{cm}^{3}\right)\end{array}$ & $\begin{array}{c}\text { Diameter } \\
(\mathrm{cm})\end{array}$ & $\begin{array}{c}\text { Number } \\
\text { per }^{2}\end{array}$ \\
\hline 90 & 160 & 90 & 3 & 756 \\
105 & 112 & 103 & 3.6 & 530 \\
340 & 45 & 336 & 5.9 & 213 \\
\hline
\end{tabular}

z90 and 340 manufactured by Beaver Plastics Ltd. (Edmonton, Alberta, Canada). 105 manufactured by Mansonville Plastics Ltd. (Surrey, British Columbia, Canada). All containers are $15 \mathrm{~cm}$ deep.

and overhead irrigation tables to minimize edge effects. The overall configuration gave us a 2 irrigation $\times 3$ container $\times 3$ block complete randomized design.

Sampling. Before each overhead irrigation, containers were placed on top of $33 \times$ $58 \times 5-\mathrm{cm}$ plastic boxes to collect leachate. Thirty to $60 \mathrm{~min}$ after overhead irrigation, once leaching subsided, leachate volume and EC (Fieldscout ${ }^{\circledR}$; Spectrum Technologies, Plainfield, IL) were measured. At this time, leachate samples and a water sample from each subirrigation tank were frozen for later $\mathrm{N}$ analysis. To capture EC trends in container media, biweekly measurements were taken by inserting the Fieldscout EC probe at three depths $(3,7$, and $11 \mathrm{~cm})$ from the top of the container.

Three months after sowing, seedling survival was determined (number of cavities with a live seedling divided by the number of cavities sown) and 15 seedlings from each irrigation $\times$ container $\times$ replication combination were harvested (45 total). Height was defined as the longest petiole length on the plant. Roots were gently washed to remove medium; shoots and roots were separated and dried at $60{ }^{\circ} \mathrm{C}$ to a constant weight and weighed. Shoot-to-root ratios were calculated for each seedling by dividing shoot biomass by root biomass. Seedling root and shoot $\mathrm{N}$ concentration was determined by MDS Harris Laboratories (Lincoln, NE) using Kjedahl digestion. Nitrogen use efficiency was calculated by dividing the nutrient content of the entire seedling by the total amount of $\mathrm{N}$ applied to the seedling. Nitrogen concentration in water samples was measured with a LECO-600 CHN analyzer (LECO Corporation, St. Joseph, MI).

Statistical analysis. Analysis of variance (ANOVA) was completed on irrigation and container main effects using the Statistical Analysis System (SAS Institute, Cary, NC) general linear model $(\alpha=0.05)$. Pairwise comparisons within main effects were analyzed using the Tukey method. When assumptions for equal variances and normality were not met, data were log-transformed to meet the required assumptions for analysis (noted in the tables and figures where applicable). Tables and figures were back-transformed to reflect the actual means and standard errors; $P$ values reflect results of $\log$-transformed analyses.

\section{Results}

Survival and morphology. Mortality ANOVA indicated a significant interaction
$(P=0.0059)$ between irrigation method and container size. Plant mortality in the overhead irrigation containers was $13 \%, 6 \%$, and $10 \%$ for the 90,105 , and 340 containers, respectively. Conversely, mortality in the subirrigation containers was zero, zero, and $1.3 \%$ for the 90,105 , and 340 containers, respectively. Irrigation main effects were significantly different for mortality $(P<$ $0.0001) ; 9 \%$ of the overhead-irrigated plants died, but mortality was only $0.4 \%$ with subirrigation. Analyses of morphological characteristics indicate subirrigated coneflowers were $15 \%$ taller with $14 \%$ more total dry weight (TDW) than overhead-irrigated seedlings (Table 2). Significant irrigation $\times$ container interactions existed for both coneflower root dry weight (RDW) and shoot-to-root ratios ( $\mathrm{S}: \mathrm{R})$. Interaction trends showed RDW increased with increasing container cavity volume for both irrigation treatments but to a greater degree for subirrigated plants. For overhead-irrigated plants, S:R increased linearly with container cavity volume while subirrigated plants decreased; neither container nor irrigation main effects were significant (data not shown).

Regardless of irrigation, overall trends showed coneflower seedlings increased in size with increasing container volume. Container size significantly affected coneflower height, shoot dry weight (SDW), and TDW (Table 2), although Tukey pairwise analysis showed no differences between the 90 and 105 container volumes for height and SDW. For all parameters, the largest means were obtained in the 340 container.

Nitrogen. Subirrigated coneflowers contained $11 \%$ more $\mathrm{N}$ (milligrams per seedling) and had a $13 \%$ higher nitrogen use efficiency (NUE) than overhead-irrigated coneflowers (Table 2). Similar to height and biomass differences, total $\mathrm{N}$ increased as container volume increased. Pairwise $\mathrm{N}$ analysis showed all coneflower container volumes differed significantly. Despite the differences in seedling $\mathrm{N}$ content, coneflower seedlings had similar NUE between container volumes (Table 2).

Leachate. The total amount of water used by plants for both irrigation treatments was similar (data not shown). Because errant spray from the overhead system (common in greenhouse environments) was unknown, differences were not determined for the total volume of water applied. All irrigation water used in the subirrigation experiment was captured, so no leachate was produced. Because main effects could not be tested for irrigation (no leaching in subirrigation treatment), analyses shifted to container main effects. Container trends showed 105 containers leaching significantly less water. Overall, significantly more $\mathrm{N}$ leached from the largest container volume compared with the smaller container volumes (Table 3; Fig. 1).

Leachate EC for overhead irrigation and subirrigation reservoir tanks was plotted for the duration of the experiment (Fig. 2). EC of overhead-irrigated coneflower leachate 
Table 2. The effect of irrigation method and container size on the morphological and nitrogen characteristics of coneflower seedlings $(93 \mathrm{~d}$ after sowing; $\mathrm{n}=45)$.

\begin{tabular}{|c|c|c|c|c|c|c|}
\hline Irrigation & Height $(\mathrm{cm})$ & Shoot dry wt (g) & Root dry wt (g) & Total dry wt (g) & Seedling N (mg) & $\begin{array}{l}\text { Nitrogen use } \\
\text { efficiency }(\%)\end{array}$ \\
\hline Subirrigation & 16.9 & 1.36 & 1.28 & 2.65 & 33.2 & 42.5 \\
\hline Significance & $<0.0001$ & 0.0924 & 0.0012 & 0.0109 & $0.0311^{z}$ & 0.0253 \\
\hline 90 & $13.1 \mathrm{a}^{\mathrm{y}}$ & $0.64 \mathrm{a}$ & $0.59 \mathrm{a}$ & $1.23 \mathrm{a}$ & $15.2 \mathrm{a}$ & 37.9 \\
\hline 105 & $14.3 \mathrm{a}$ & $0.87 \mathrm{a}$ & $0.80 \mathrm{~b}$ & $1.67 \mathrm{~b}$ & $19.9 \mathrm{~b}$ & 42.3 \\
\hline 340 & $19.5 \mathrm{~b}$ & $2.37 \mathrm{~b}$ & $2.13 \mathrm{c}$ & $4.50 \mathrm{c}$ & $58.9 \mathrm{c}$ & 39.0 \\
\hline
\end{tabular}

${ }^{\mathrm{z} P}$ value represents log-transformed data.

${ }^{\mathrm{y}}$ Mean separation within columns by Tukey $(P<0.05)$.

Table 3. The effect of container size on cumulative leaching characteristics of coneflower seedlings grown in an overhead irrigation treatment (93 d after harvest; $n=45$ ).

\begin{tabular}{lcc}
\hline Container & $\begin{array}{c}\text { Water } \\
\text { leached }(\mathrm{L})\end{array}$ & $\begin{array}{c}\text { Nitrogen } \\
\text { leached }(\mathrm{mg})\end{array}$ \\
\hline 90 & $38.9 \mathrm{a}^{\mathrm{y}}$ & $0.78 \mathrm{a}$ \\
105 & $21.1 \mathrm{~b}$ & $0.67 \mathrm{a}$ \\
340 & $30.5 \mathrm{ab}$ & $2.85 \mathrm{~b}$ \\
Significance & 0.0073 & $<0.0001^{\mathrm{z}}$ \\
\hline
\end{tabular}

${ }^{z} P$ value represents log-transformed data.

${ }^{\mathrm{y}}$ Mean separation within columns by Tukey $(P<0.05)$.

was initially high but dropped 53\% and remained low for the remainder of the growing season. EC of subirrigation reservoir tank effluent remained nearly constant throughout the measurement period.

Media. Potting media EC was measured for each irrigation treatment. For subirrigated seedlings, higher EC readings were observed in the upper portion of the container (Fig. 3). Overhead irrigation maintained similar values throughout the soil profile.

\section{Discussion}

Seedling survival and morphology. Our results indicate subirrigation was effective in keeping mortality rates low while maintaining or improving seedling quality compared with traditional overhead irrigation systems. Biernbaum (1990) suggests that uniformity of watering is one of the greatest benefits of subirrigation, because it creates uniform media moisture. Because coneflower SDW means were similar between irrigation treatments, suggesting similar leaf area (Table 2), we attributed decreased mortality in subirrigated coneflowers to improved water access and decreased canopy deflection of water. Similar to the observations of Beeson and Knox (1991), we expected decreased overhead irrigation efficiency in the low-volume, high-density containers as a result of canopy water reflectance. This effect would contribute to uneven watering, drought stress, and ultimately mortality for seedlings receiving inadequate water. As expected, we then observed highest mortality in the smallest highdensity containers. Unexpectedly, we saw the lowest mortality in the midsized, middensity container. Without a discernible trend, the significant irrigation treatment $\times$ container volume interaction makes conclusions on the

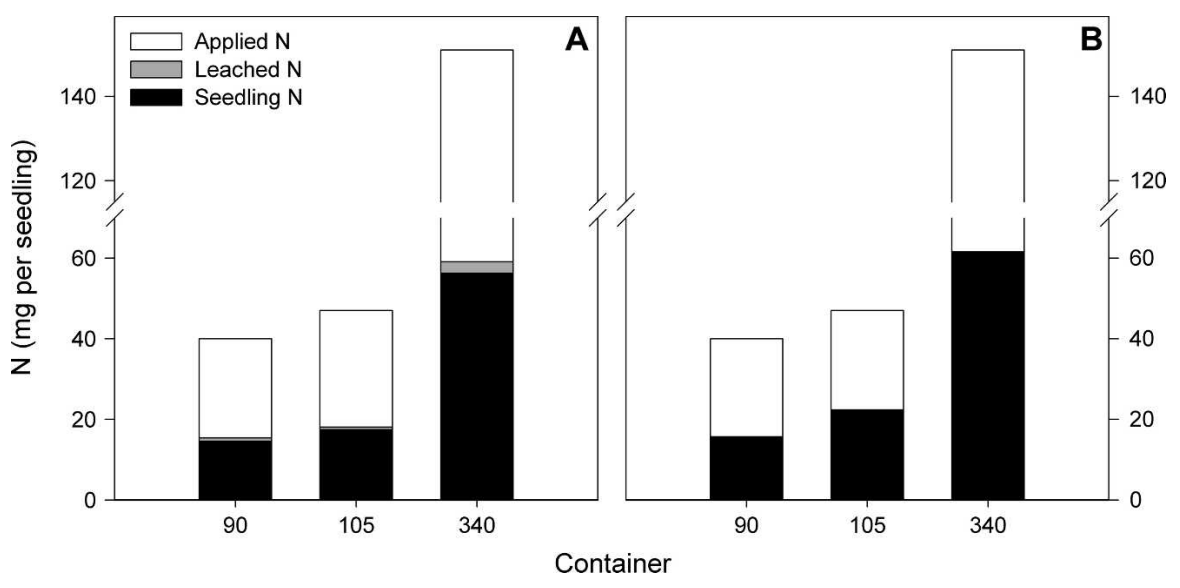

Fig. 1. Applied, leached, and seedling nitrogen values for overhead-irrigated coneflowers (A) and subirrigated coneflowers (B).

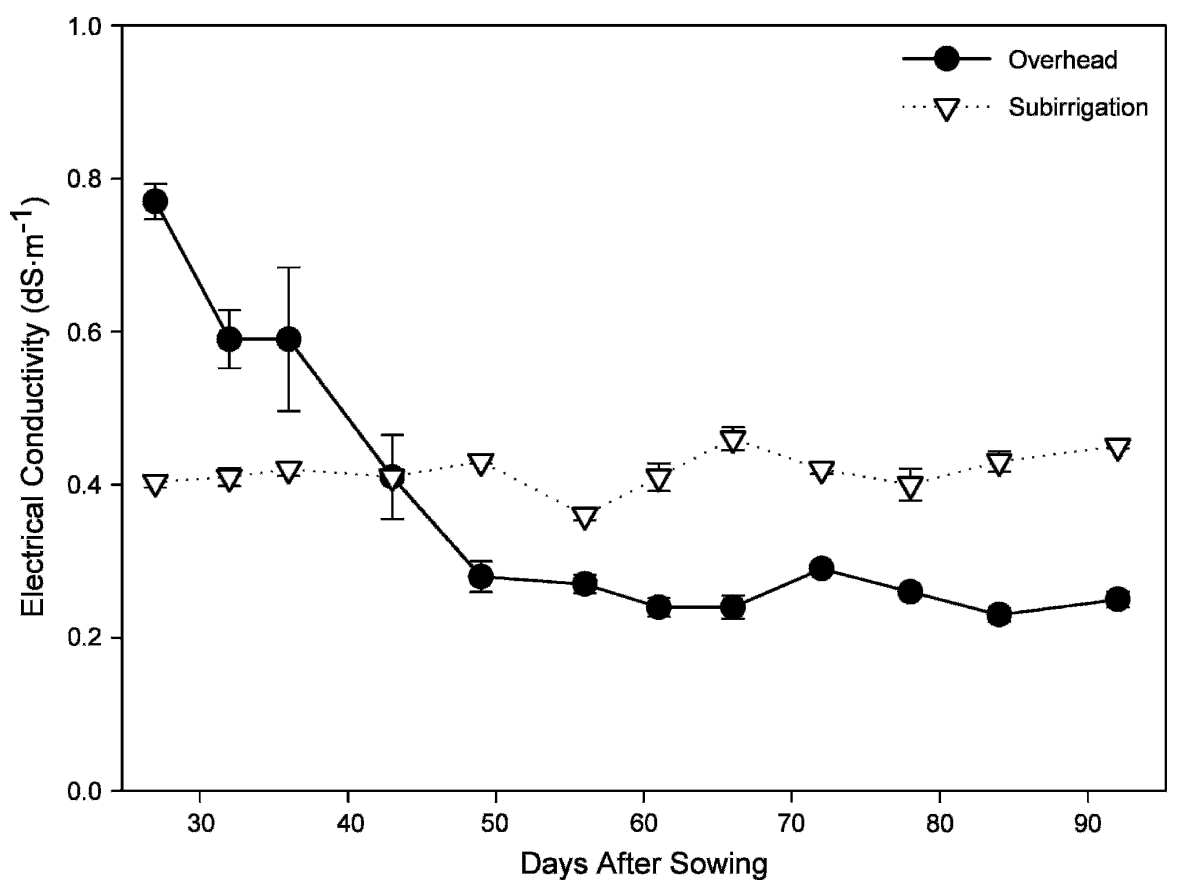

Fig. 2. Electrical conductivity of overhead-irrigated and subirrigated coneflower. Bars indicate SES of the means.

contribution of container volume or density to mortality difficult to draw.

Morphologically, subirrigated coneflower seedlings performed as well or better than overhead-irrigated seedlings, similar to results with vegetable and ornamental seed- lings (Ahmed et al., 2000; Argo and Biernbaum, 1995; Kang et al., 2004; Morvant et al., 2001; Santamaria et al., 2003; Wilson et al., 2003). Our data show that subirrigated coneflowers were taller and had greater root and total dry weights - desirable characteristics 


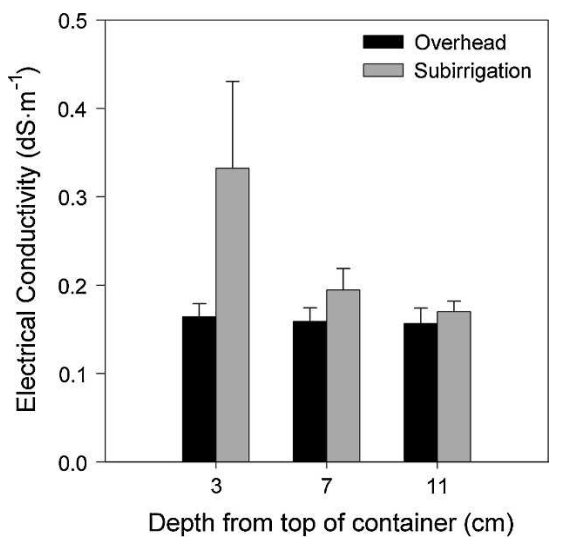

Fig. 3. Electrical conductivity values for overhead and subirrigated coneflower seedling medium at three depths $(3,7$, or $11 \mathrm{~cm})$ from the top of the container. Measurements were taken $93 \mathrm{~d}$ after sowing. Bars indicate SE means of three replications.

for seedlings to be outplanted (Thompson, 1985). The enhanced growth may be the result of improved mineral nutrition from uniform irrigation and the recycling of nutrients from the reservoir tank or because more fertilizer is leached out of overheadirrigated containers (Hicklenton and Cairns, 1996) and thus no longer available for plant growth.

Overall, container volume caused significant effects with height and dry weights increasing with increasing volume. Our findings are consistent with the review by NeSmith and Duval (1998) and studies of container Pinus pinea seedlings (Dominguez-Lerena et al., 2006). Most differences in plant growth, foliar $\mathrm{N}$ content, and $\mathrm{N}$ leaching were observed in the largest container (340), which had $67 \%$ more volume than the midsized container (105) compared with the $20 \%$ difference between the small (90) and midsized containers. Because containers can physically restrict root systems, it follows that this has an effect on both water and nutrient availability (McConnughay and Bazzaz, 1991). Consequently, containers that offer more volume, and increased water and fertilizer availability, allow greater growth.

A potential concern with this study was the logistical design of the subirrigation watering regime. When one container required watering, all three containers were irrigated, allowing the possibility of confounding irrigation across the containers in the subirrigation treatment (Pinto, 2005). Despite this, our irrigation records showed subirrigated 105 and 340 containers received only five and four more irrigations, respectively, than their overhead-irrigated cohorts over the course of the growing season. Conversely, overhead-irrigated 160 containers received two more irrigations than 160 subirrigation containers. These additional irrigations occurred early in the seedlings' development, within the first 4 weeks, whereas the remaining irrigations occurred at the same intervals. After 4 weeks of growth, seedlings in the larger volumes were proportionally larger as well so that water was removed from the medium by plants at similar rates, resulting in drydowns to $85 \%$ field capacity occurring at similar intervals. In the overhead irrigation treatments, the largest volume container had $70 \%$ more biomass than the smallest; this was similar to the $74 \%$ for the same volumes in subirrigated containers, suggesting no compromise by the few additional, early irrigations. Although the subirrigated 105 and 340 containers were irrigated a little more, the additional irrigations were when seedlings were small, and an $85 \%$ drydown rate for overhead-irrigated 105 and 340 containers would not be deemed stressful. Consequently, our results still suggest increased growth with container volume and zero water loss and leaching with subirrigation. Additionally, our study shows potential for irrigating coneflowers in different volume containers within the same subirrigation tray without major consequence.

Nitrogen. Our analyses showed that subirrigated coneflowers contained more $\mathrm{N}$ (milligrams per per seedling) and had higher NUE. We hypothesize that because no fertilizer was discharged from the system, the possibility of recycling nutrients, including $\mathrm{N}$, becomes higher, thereby increasing NUE and content. Morvant et al. (2001) demonstrated that the use of a subirrigation system, combined with controlled-release fertilizer, contributed to the high retention of $\mathrm{N}$ in plants and medium and consequently higher biomass of geraniums (Pelargonium $\times$ hor torum 'Pinto Red'). Concomitant with the possibility of recycling nutrients, our subirrigated coneflowers also developed larger root biomass, thereby allowing the possibility of greater nutrient uptake through greater root surface areas.

Container main effects for $\mathrm{N}$ followed trends similar to those of plant growth characteristics. As container volume increased, so did $\mathrm{N}$ content. This follows trends also seen by Dominguez-Lerena et al. (2006) for pine seedlings in production nurseries. Nitrogen use efficiencies showed no difference with container volume.

Leachate. After 6 weeks, coneflower seedlings were large enough to exploit $\mathrm{N}$ released from controlled-release fertilizer, thereby depleting N. Ninety-three days after sowing, $\mathrm{N}$ leaching levels were less than 0.5 mg per seedling (Fig. 4B). EC also provided a supplemental method for tracking $\mathrm{N}$ leachate (Fig. 2). By the end of the experiment, EC measurements for both irrigation treatments were near the baseline irrigation water (no fertilizer added) measurement of $0.4 \mathrm{dS} \cdot \mathrm{m}^{-1}$. The use of these data and the methods described by Birrenkott et al. (2005) allowed us to track part of the nutrient budgets and uptake efficiencies for our seedlings (Fig. 1). Nitrogen leached from overhead-irrigated coneflowers amounted to only $2 \%$ of the total applied. We speculate this low value is the result of the efficiency of controlled-release fertilizer over the application of liquid fertilizers as seen for geranium seedlings by Morvant et al. (2001).

A considerable amount of applied $\mathrm{N}$ was unaccounted for in the seedlings or leachate. Although we did not measure media $\mathrm{N}$ content, we suspect some $\mathrm{N}$ was being retained as a result of the high cation exchange capacity of the peat-vermiculite medium (Landis et al., 1990). Despite N not being measured in the media directly, EC of the media profile was measured to characterize the buildup of fertilizer salts. Generally, coneflower medium EC was low for both irrigation treatments, indicating depletion of fertilizer salts, but subirrigation EC levels were $48 \%$ higher in the upper profile of the medium. Studies commonly report high concentrations of soluble salts within the top layer of medium with subirrigation (Argo and Biernbaum, 1995; Kent and Reed, 1996; Richards and Reed, 2004; Todd and Reed, 1998). Todd and Reed (1998) also show the upper portion of the container is where the least amount of root dry weight can be found for New Guinea Impatiens (Impatiens hawkeri Bull.). We saw similar results with both EC stratification and root mass in coneflower seedlings at the time of harvest, although salt levels in the upper media profile suggest toxicity (Fig. 3; Scoggins, 2005).

In summary, subirrigation was an effective alternative to produce coneflower seedlings because seedling size and $\mathrm{N}$ use efficiencies were increased, less $\mathrm{N}$ was leached, and mortality was reduced. Additionally, data supported the use of different

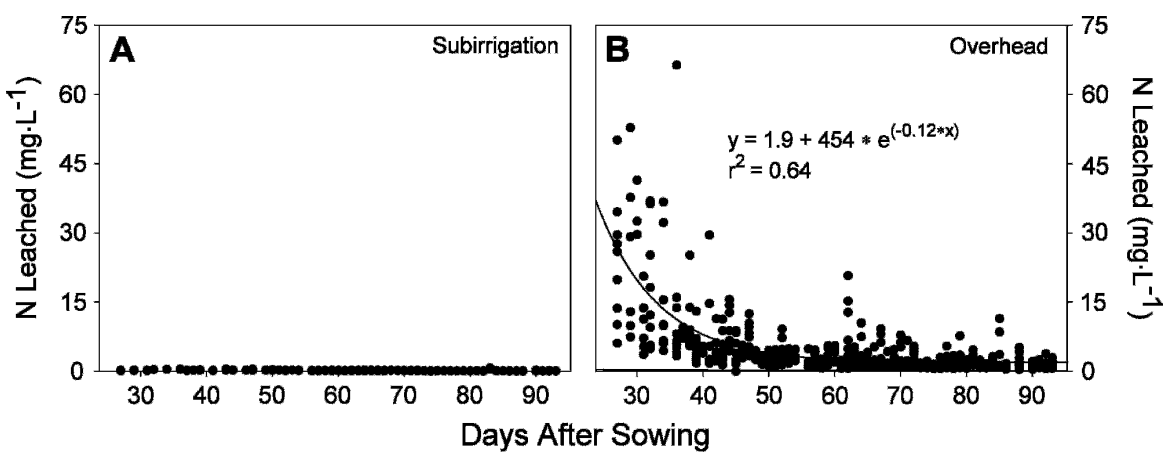

Fig. 4. Leached concentrations of nitrogen for subirrigated coneflower (A) and overhead-irrigated coneflower (B) seedlings grown with controlled-release fertilizer in a greenhouse for $93 \mathrm{~d}$. Each datum point represents one replicate. 
container volume without compromise to seedling quality or NUE. Although we experienced no problems with disease, caution should be used with subirrigation systems, especially when dealing with roots and the sharing of water from the recirculation tank (Coggeshall and Van Sambeek, 2001). Nevertheless, our study showed that quality seedlings were produced without expelling potentially harmful leachate water while showing the potential for production with some water savings (assuming subirrigation tanks are not repeatedly emptied and refilled). Even small seedling production areas have the potential to contaminate groundwater with fertilizer runoff, particularly if the same area is used for the same type of production for years as is true for most forest nurseries (Juntenen et al., 2002). The ability to produce native plants without the production of nutrient-rich runoff will be a boon to nurseries hoping to reduce their environmental contamination impact and water use while at the same time producing quality seedlings.

\section{Literature Cited}

Ahmed, A.K., G.C. Cresswell, and A.M. Haigh. 2000. Comparison of sub-irrigation and overhead irrigation of tomato and lettuce seedlings. J. Hort. Sci. Biotechnol. 75:350-354.

Argo, W.R. and J.A. Biernbaum. 1995. The effect of irrigation method, water-soluble fertilization, preplant nutrient charge, and surface evaporation on early vegetative and root growth of poinsettia. J. Amer. Soc. Hort. Sci. 120:163-169.

Beeson R.C., Jr. and G.W. Knox. 1991. Analysis of efficiency of overhead irrigation in container production. HortScience 26:848-850.

Biernbaum, J.A. 1990. Get ready for subirrigation. Greenhouse Grower. 8:130-133.

Biernbaum, J.A. 1992. Root-zone management of greenhouse container grown crops to control water and fertilizer use. HortTechnology 2: 127-132.

Birrenkott, B.A., J.L. Craig, and G.R. McVey. 2005. A leach collection system to track the release of nitrogen from controlled-release fertilizers in container ornamentals. HortScience 40:1887-1891.

Coggeshall, M.V. and J.W. Van Sambeek. 2001. Development of a subirrigation system with potential for hardwood tree propagation. Proc. Intl. Plant Prop. Soc. 51:443-448.
Dominguez-Lerena, S., N.H. Sierra, I.C. Manzano, L.O. Bueno, J.L.P. Rubira, and J.G. Mexal. 2006. Container characteristics influence Pinus pinea seedling development in the nursery and field. For. Ecol. Manage. 221:63-67.

Dumroese, R.K., D.F. Jacobs, A.S. Davis, J.R. Pinto, and T.D. Landis. 2007. An introduction to subirrigation in forest and conservation nurseries and some preliminary results of demonstrations. Natl. Proc. For. Conservation Nursery Assoc. USDA For. Serv. (in press).

Dumroese, R.K., J.R. Pinto, D.F. Jacobs, A.S. Davis, and B. Horiuchi. 2006. Subirrigation reduces water use, nitrogen loss, and moss growth in a container nursery. Native Plants J. 7:253-261.

Dumroese, R.K., D.L. Wenny, and D.S. PageDumroese. 1995. Nursery waste water: The problem and possible remedies. Natl. Proc. For. Conservation Nursery Assoc. USDA For. Serv. Gen. Tech. Rep. PNW-GTR-365. p. 89 97.

Fare, D.C., C.H. Gilliam, and G.J. Keever. 1994 Cyclic irrigation reduces container leachate nitrate-nitrogen concentration. HortScience 29:1514-1517.

Grey, D. 1991. Eliminate irrigation runoff: Oregon's new plan. The Digger 26:21-23.

Hicklenton, P.R. and K.G. Cairns. 1996. Plant water relations and mineral nutrition of containerised nursery plants in relation to irrigation method. Can. J. Plant Sci. 76:155-160.

Juntenen, M.L., T. Hammar, and R. Rikala. 2002. Leaching of nitrogen and phosphorus during production of forest seedlings in containers. J. Environ. Qual. 31:1868-1874.

Kang, J.G., M.W. van Iersel, and K.S. Nemali. 2004. Fertilizer concentration and irrigation method affect growth and fruiting of ornamental pepper. J. Plant Nutr. 27:867-884.

Kent, M.W. and D.W. Reed. 1996. Nitrogen nutrition of New Guinea Impatiens 'Barbados' and Spathiphyllum 'Petite' in a subirrigation system. J. Amer. Soc. Hort. Sci. 121:816-819.

Landis, T.D., R.W. Tinus, S.E. McDonald, and J.P. Barnett. 1990. The container tree nursery manual, vol. 2, containers and growing media. Agr. Hdbk. 674. USDA For. Serv., Washington, DC. Leskovar, D.I. 1998. Root and shoot modification by leaching. HortTechnology 8:510-514.

McAvoy, R.J., M.H. Brand, E.G. Corbett, J.W. Bartok, Jr., and A. Botacchi. 1992. Effect of leachate fraction on nitrate loading to the soil profile underlying a greenhouse crop. J. Environ. Hort. 10:167-171.

McConnughay, K.D.M. and F.A. Bazzaz. 1991. Is physical space a soil resource? Ecol. 72:94103.
Molitor, H.D. 1990. The European perspective with emphasis on subirrigation and recirculation of water and nutrients. Acta Hort. 272:165-174.

Morvant, J.K., J.M. Dole, and J.C. Cole. 2001. Fertilizer source and irrigation system affect geranium growth and nitrogen retention. HortScience 36:1022-1026.

Neal, K. 1989. Subirrigation. Greenhouse Manager $7: 83-88$.

Ne Smith, D.S. and J.R. Duval. 1998. The effect of container size. HortTechnology 8:495-498.

Oka, P. 1993. Surviving water restrictions. Amer. Nurseryman 178:68-71.

Pinto, J.R. 2005. Container and physiological status comparisons of Pinus ponderosa seedlings. Univ. of Idaho, Moscow, ID. MS Thesis.

Richards, D.L. and D.W. Reed. 2004. New Guinea Impatiens growth response and nutrient release from controlled-release fertilizer in a recirculating subirrigation and top-watering system. HortScience 39:280-286.

Santamaria, P., G. Campanile, A. Parente, and A. Elia. 2003. Subirrigation vs. drip-irrigation: Effects on yield and quality of soilless grown cherry tomato. J. Hort. Sci. Biotechnol. 78:290-296.

Scoggins, H.L. 2005. Determination of optimum fertilizer concentration and corresponding substrate electrical conductivity for ten taxa of herbaceous perennials. HortScience 40:15041506.

Thompson, B.E. 1985. Seedling morphological evaluation-What you can tell by looking. Evaluating seedling quality: Principles, procedures, and predictive abilities of major tests. Forest Research Laboratory, Oregon State University, Corvallis, OR. p. 59-71.

Todd, N.M. and D.W. Reed. 1998. Characterizing salinity limits of New Guinea Impatiens in recirculating subirrigation. J. Amer. Soc. Hort. Sci. 123:156-160.

Uva, W.L., T.C. Weiler, and R.A. Milligan. 1998. A survey on the planning and adoption of zero runoff subirrigation systems in greenhouse operations. HortScience 33:193-196.

White, J.W. and J.W. Marstalerz. 1966. Soil moisture as related to container capacity. Amer. Soc. Hort. Sci. 89:758-765.

Wilson, S.B., P.J. Stoffella, and D.A. Graetz. 2003. Compost amended media and irrigation system influence containerized perennial Salvia. J. Amer. Soc. Hort. Sci. 128:260-268.

Yeh, D.M., P.J. Hsu, and J.G. Atherton. 2004. Growth and flowering responses of Canna $\times$ generalis to nitrogen supplied to the growing medium via top- or sub-irrigation. J. Hort. Sci. Biotechnol. 79:511-514. 